\title{
"Amor" e "morte" nos madrigais de Carlo Gesualdo: um estudo sobre o desenvolvimento da escrita musical e textual
}

\author{
"Love" and "death" in the madrigals of Carlo Gesualdo: \\ a study on the development of music and text writing
}

\author{
Rafael Luís Garbuio ${ }^{1}$ \\ Carlos Fernando Fiorini ${ }^{2}$ \\ ${ }^{1}$ Universidade Estadual de Campinas, Campinas, SP, Brasil. \\ rafaelgarbuio@gmail.com \\ ${ }^{2}$ Universidade Estadual de Campinas, Campinas, SP, Brasil. \\ fiorini.carlos@gmail.com
}

\section{Resumo:}

A escrita musical do compositor Carlo Gesualdo transforma-se ao longo de seus seis livros de madrigais. Enquanto nos aspectos que integram os dois primeiros livros encontramos principalmente características da tradição polifônica do Renascimento, nos madrigais dos terceiro e quarto livros predomina o experimentalismo harmônico, ao passo que nos dois últimos há maior ocorrência dos procedimentos tipicamente associados ao compositor maduro - a escrita cromática e dissonante. O principal elemento que faz a ligação desta escrita ao longo das três fases é a relação entre a música e o texto. Observando o tratamento que o compositor fez em relação a dois termos recorrentes nos madrigais - as palavras amor e morte -, em obras de diferentes fases, foi possível constatar o estreitamento desta relação textual da música, bem como suas implicações no resultado sonoro final. Na primeira fase, Gesualdo utilizava os procedimentos mais comuns na escrita musical para ressaltar estes termos, como a escrita contrapontística, contrastando com a escrita homofônica. Nas fases seguintes, ele passou a procurar elementos musicais mais sofisticados que permitissem explorar diferentes sonoridades. Por meio deste processo, o compositor destacou, de forma mais contundente, palavras e narrações dos poemas, recorrendo principalmente a resultantes 
harmônicas incomuns e a falsas relações melódicas. A análise do uso destes termos ao longo da obra demonstrou o aprofundamento da expressividade e o amadurecimento dos procedimentos musicais utilizados pelo compositor.

Palavras-chave: Renascimento; madrigal italiano; Carlo Gesualdo; música e texto.

\begin{abstract}
:
Gesualdo's compositional writing evolves throughout his six books of madrigals. While the first two books bring the polyphonic tradition of Renaissance, the harmonic experimentalism predominates in the madrigals of the third and fourth books. However, in the last two, there is a higher frequency of the procedures typically associated with the mature composer - the chromatic and dissonant writing. The main element that connects his writing along the three periods is the relation between music and text. Observing the treatment given by the composer to two words in the madrigals - love and death - from different periods, it is possible to confirm his increasing text painting and its implications in the resulting sound. In the first period, Gesualdo used the most common procedures, such as the contrast between counterpoint and homophony. In the following periods, he began to look for more sophisticated musical elements in order to explore different sounds. Through this process, the composer vigorously emphasized words and, thus, the narrative of the poems, reaching for uncommon harmonic resultants and false melodic relations. The analysis of these words in procedures by Gesualdo reveals his deepening of expressivity and a maturing style.
\end{abstract}

Keywords: Renaissance; Italian madrigal; Carlo Gesualdo; music and text.

Data de recebimento: 02/04/2015

Data de aprovação final: 20/09/2015

\title{
1 - Introdução
}

A obra composta pelo italiano Carlo Gesualdo em fins do Século XVI representa o último estágio da música do Renascimento. Sua linguagem harmônica é considerada, até hoje, como ousada e extravagante, pois traz consigo os principais elementos de um segmento do 
repertório renascentista que se caracterizou pelo experimentalismo sonoro: os madrigais italianos tardios.

Gesualdo compôs e publicou em vida seis livros de madrigais a cinco vozes. Estas obras ficaram conhecidas pela escrita cromática e dissonante, que passaria a ser muito associada à obra deste compositor. A base principal destas composições é a polifonia vocal que se desenvolveu ao longo do Renascimento. O desenvolvimento da polifonia até os estágios avançados do fim do período é atribuído à junção da técnica polifônica trazida pelos compositores franco-flamengos à península italiana com a tradição melódica já existente. Mas o que torna a obra de Gesualdo tão distinta do que foi feito anteriormente neste período, e mesmo do que seria produzido posteriormente a ele, são as relações harmônicas provenientes da textura polifônica. A manipulação das resultantes triádicas desta escrita foi amplamente utilizada pelo compositor como ferramenta para expressar, na música, passagens e humores do texto. Desta forma, temos na relação estabelecida entre a música e o texto uma importante fonte de informações sobre as concepções musicais dos madrigais. As dificuldades técnicas apresentadas por estas obras não impediram o reconhecimento de seu valor artístico, mas geraram uma lacuna de pesquisas musicais aprofundadas sobre este assunto. $\mathrm{O}$ que temos de forma vasta são trabalhos dedicados à biografia do compositor, nos quais muitos dos madrigais são elencados e analisados, mas sem que a questão harmônica fosse diretamente esclarecida. Acabou-se criando um rótulo de virtuosismo sobre estes madrigais que, em comparação com outras expressões do mesmo período, tornam-os menos presentes nas salas de concerto do que poderiam.

Para facilitar o entendimento e possibilitar um aprofundamento na concepção musical empregada pelo compositor, os seis livros podem ser divididos em três fases cronológicas. Esta divisão apresenta uma coerente relação estilística com características distintas que apontam para o amadurecimento da escrita de Gesualdo. Glenn Watkins, em seu livro sobre a vida e a obra do compositor, Gesualdo: The Man and His Music (WATKINS, 1991), deixa claro a existência de uma linha estrutural que separa as publicações dos seis livros em três fases. Segundo ele, a primeira fase abrange os dois primeiros livros, que foram publicados em 1594. Os livros três e quatro, compostos entre 1594 e 1596, caracterizariam a segunda fase. E os dois últimos pertenceriam à terceira fase, sendo estes compostos e publicados 
posteriormente, em 1596. O elemento histórico que respaldaria esta divisão é a ida de Gesualdo para a cidade de Ferrara no ano de 1594 e o contato que ele lá teria com uma atmosfera artística bastante avançada. A cidade de Ferrara, localizada ao norte da península italiana, era conhecida na época pela pujança artística que possuía, fato que teria exercido relevante influência sobre a obra do compositor. E, de acordo com WATKINS, o convívio com a música desta cidade alterou drasticamente a escrita de seus madrigais (1991,p.37). Colaborando com esta divisão da obra em três fases e com a importância da ida de Gesualdo à cidade de Ferrara, temos o autor Pietro Misuraca, quem no livro Carlo Gesualdo, Principe di Venosa (MISURACA, 2000), atesta que nos livros três e quatro, portanto a segunda fase, temos a "revolta" de Gesualdo ou o surgimento de seu estilo próprio (2000, p.89), o que coincide com seu contato com a cidade.

Até mesmo os grupos vocais especializados na execução deste repertório atestam a existência destas fases estilísticas. O grupo The Kassiopeia Quintet, lançou no ano de 2010 a gravação completa dos seis livros de madrigais de Gesualdo. No encarte do CD, a edição deixa claro que há diferenças entre os livros:

\footnotetext{
O Livro I tem equilíbrio, mas sem qualquer assinatura individual; o livro II é conservador e quase ingênuo, o livro III é uma exploração da linguagem, o Livro IV termina um período e começa outro, o livro $\mathrm{V}$ encontra um equilíbrio perfeito e o livro VI é uma experiência muito bem sucedida (VISSER, 2010, p.4)
}

Mesmo não fazendo referência direta às três fases de composição, o texto que consta no encarte da coleção de CDs atribui características aos seis livros que vão ao encontro do que dizem WATKINS e MISURACA. Os dois primeiros marcados pela escrita mais tradicional, ou conservadora, os dois centrais explorando um novo estilo e os últimos estabilizando-se no estilo próprio do compositor.

A simples divisão destes livros em três fases e o reconhecimento de suas respectivas semelhanças técnicas não resolvem por completo a dificuldade no entendimento destas obras, pois, muitos dos procedimentos que dificultam a análise da escrita estão presentes nas três fases, com aprofundamentos diferentes, mas com as mesmas características. No entanto, a relação que se constrói entre a música e o texto pode nos dar uma série de parâmetros técnicos para entendermos de forma mais efetiva a concepção musical utilizada pelo 
compositor. Fica evidente que esta relação foi se estreitando ao longo dos livros. Um importante indício deste estreitamento é o fato de ter Gesualdo composto a maioria dos madrigais da primeira fase sobre textos de poetas conhecidos da época, ao passo que os livros da segunda fase apresentam muitos textos baseados em poemas pré-existentes, mas com alterações significativas promovidas pelo compositor. Por sua vez, os madrigais da última fase são todos escritos sobre textos do próprio compositor; ou seja, na medida em que amadurecia a escrita, a relação textual tornava-se tão intensa que o compositor aboliu a figura do poeta, assumindo a concepção da música e do poema como um ato único.

Se somarmos a isso o fato de ter o compositor recorrido a alguns temas repetidamente ao longo de sua carreira, encontramos algumas palavras que são constantes ao longo das três fases. Estes termos, devido à sua carga expressiva e à sua importância na narrativa poética desenvolvida por Gesualdo, nos traz mais do que um único significado, pois se trata de todo um contexto dramático junto. Assim, ao analisar o emprego e o tratamento musical que o compositor dispensa a uma mesma palavra ao longo das três fases, podemos traçar um panorama musical condizente com esta divisão a partir da relação entre música e texto.

Este trabalho elegeu os termos amor e morte como sendo dois importantes conceitos textuais presentes ao longo dessas fases. Por meio delas, foi realizada uma análise musical em diferentes momentos da escrita do compositor, de forma a compará-las. Assim, foi possível identificar algumas diferenças técnicas entre cada uma das três fases estilísticas de Gesualdo. A palavra amor é recorrente em todos os livros de Gesualdo, e aparece também nos madrigais de outros compositores. Já, a palavra morte, que também é bastante utilizada, encontra na obra de Gesualdo um espaço especial. Os aspectos psicológicos do compositor e sua atenção à tragédia amorosa faz com que este termo seja constante nas narrações, especialmente nos últimos livros, quando o autor dos poemas é o próprio compositor (IUDICA, 1993, p.100). Por estes motivos, estas duas palavras oferecem-nos parâmetros para traçarmos uma visão geral sobre a relação entre música e texto nos madrigais. Além disso, por meio delas, poderemos identificar as principais diferenças ao longo das três fases de composição. 


\section{2 - Amor e Morte nos madrigais de Gesualdo}

O termo amor traz consigo uma dubiedade que foi explorada pelo compositor. É possível atribuir a esta palavra uma atmosfera plácida de contentamento e de felicidade, quando ela se insere em um contexto de amor correspondido e feliz, ou em uma atmosfera torturante e dolorida de um amor infeliz. Gesualdo trabalhou estas duas vertentes do significado, e construiu passagens musicais condizentes a elas.

No início do nono madrigal do primeiro livro, temos a palavra utilizada com o sentido positivo do termo. Na frase que abre a obra, o narrador refere-se à sua interlocutora como sendo o seu "amor", e lhe diz que não deseja a paz. Esta informação, em conjunto com o restante do texto, pressupõe o interesse do narrador naquele sentimento, estando inclusive disposto a abrir mão da paz por ele. Observa-se que a escrita homofônica e a pausa que interrompe a frase demonstram musicalmente a própria paz a que o texto se refere, como nos demonstra a figura abaixo retirada do primeiro livro de madrigais do compositor:

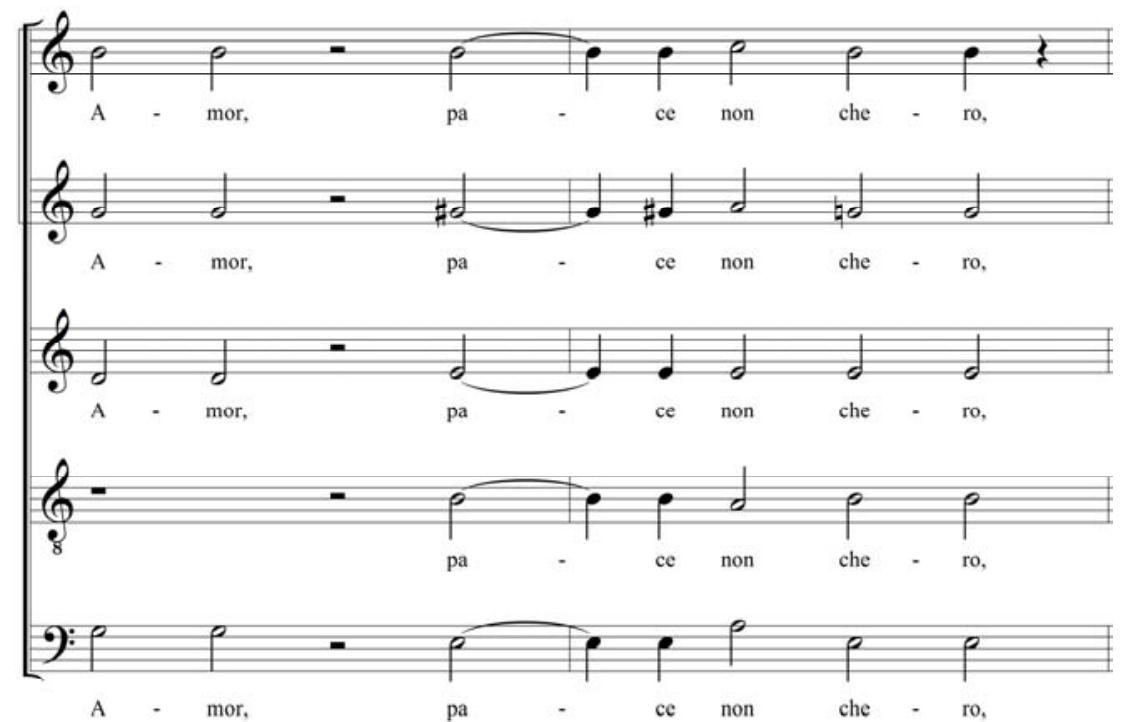

Figura 1: Amor, pace non chero - Livro I - c.1-2

Apesar da alteração melódica na tríade sobre a nota Mi, este trecho não se caracteriza como dissonante, o que temos é uma instabilidade na escala do modo escolhido, gerando algumas 
alterações pontuais. Estas alterações presentes na primeira fase diferem das demais por não serem usadas como recurso retórico.

Outro exemplo desta palavra utilizada com o sentido de "uma atmosfera de paz e felicidade" aparece no segundo livro em seu madrigal Nè tien face o saetta (Não tem face nem flecha). Assemelhando-se com o exemplo anterior, o compositor utiliza a palavra para se referir à interlocutora, ou seja, à sua amada.

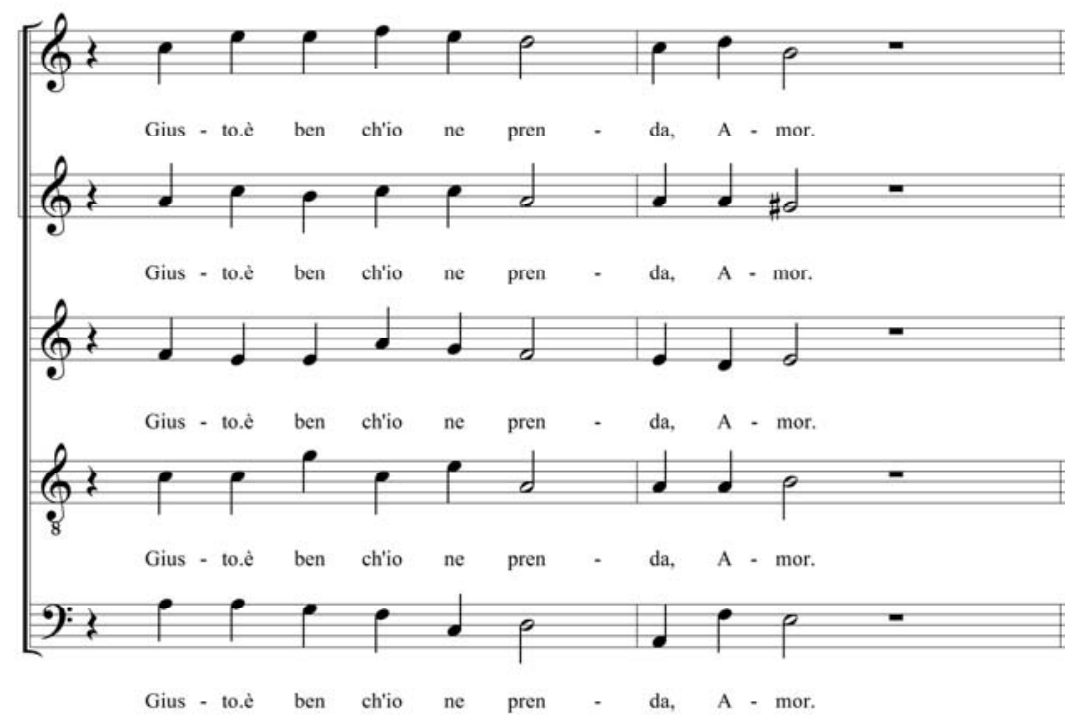

Figura 2: Nè tien face o saetta - Livro II - c.9-10

Mais uma vez, observa-se que a escrita homofônica demonstra um sentimento de tranquilidade da narração. E nos chama atenção a forma como o discurso musical coloca a palavra amor como um vocativo. A vírgula colocada antes dela conduz a uma prosódia textual que representa um discurso entre pessoas com intimidade, o que denota um tratamento carinhoso. Este ambiente tranquilo é reproduzido pela música, que traz poucas alterações, e está concentrado na região média das vozes, o que garante um resultado sonoro equilibrado. O ritmo sobre o qual a palavra é escrita contribui para o efeito textual ao acentuar sua sílaba tônica.

Voltando ao seu primeiro livro, encontra-se um exemplo que se encaixa na segunda forma de utilização deste mesmo termo: o sétimo madrigal, que trata da narração de um sentimento que confere dor e tormentos ao narrador. Em uma das passagens, a interlocutora do narrador 
também é chamada de amor, mas agora é descrita como vil e perigosa. Neste contexto, a escrita musical é apresentada com movimentos rítmicos mais rápidos, sugerindo uma tensão no ambiente criado pelo texto. A técnica polifônica utilizada no trecho relaciona-se com a tradição do Renascimento, pois temos como principais características a simetria e o equilíbrio da escrita. O intervalo de tempo entre as entradas das vozes na frase Vile ape, Amor (Vil abelha, Amor) é sempre de duas semínimas, e a forma destas entradas, que intercala dupla de vozes com apenas uma voz, também demonstra a preocupação com o equilíbrio. Também fica clara a relação que existe entre o motivo rítmico das vozes, pois, nas três superiores os motivos são iguais e nas duas inferiores apresentam semelhanças consideráveis. Por meio desta similaridade rítmica, obtém-se um fácil entendimento do motivo principal.

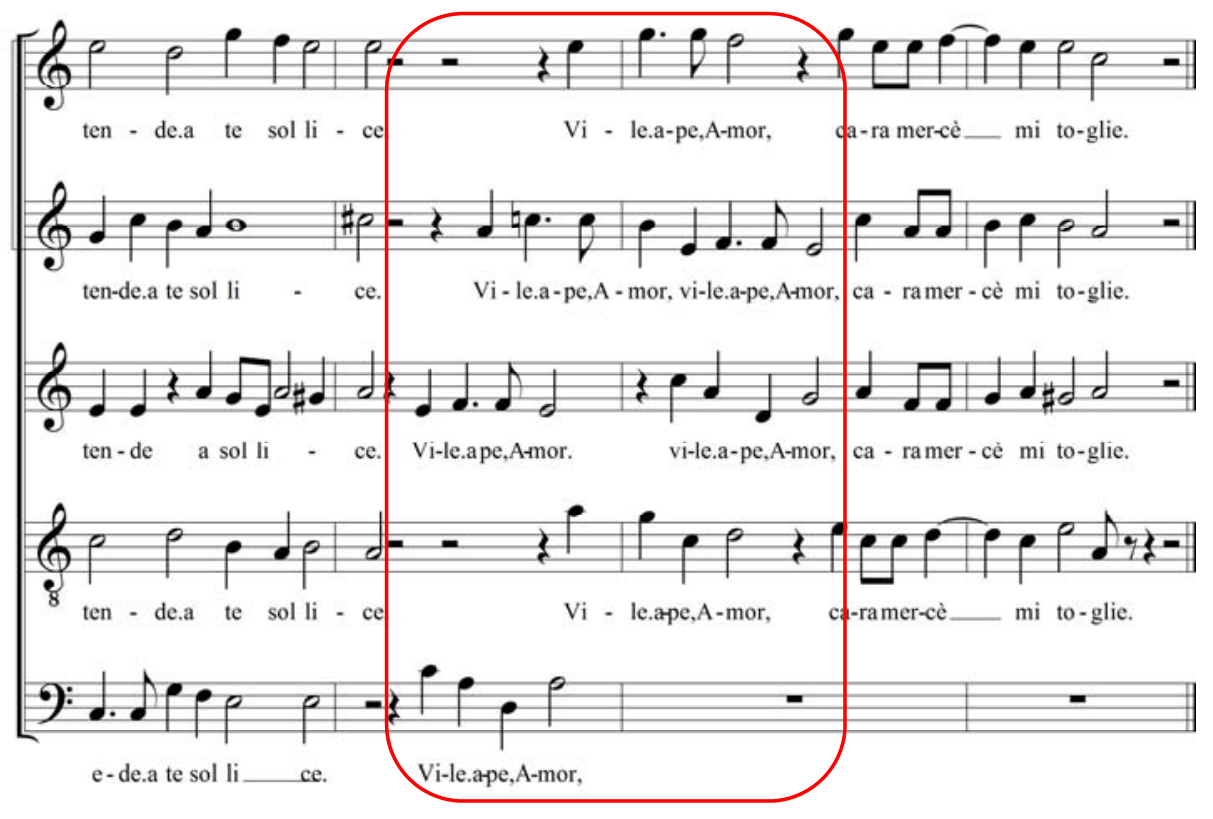

Figura 3: Ahi, troppo saggia nell'errar - Livro I - c.11-14

O equilíbrio contrapontístico demonstrado pela figura, também está em acordo com a clareza da seção textual. O contraponto apenas irá apresentar outro trecho, ou seja, outra frase, quando todas as vozes tiverem encerrado a frase anterior e demarcarem o início e o fim desta sessão.

Ainda no segundo livro, deparamo-nos com o exemplo do madrigal Candida man qual neve (Mãos cândidas como a neve), o décimo quinto. Neste exemplo, observa-se o uso mais 
constante de algumas alterações melódicas, que mantêm, contudo, as características do contraponto em acordo com os últimos exemplos.

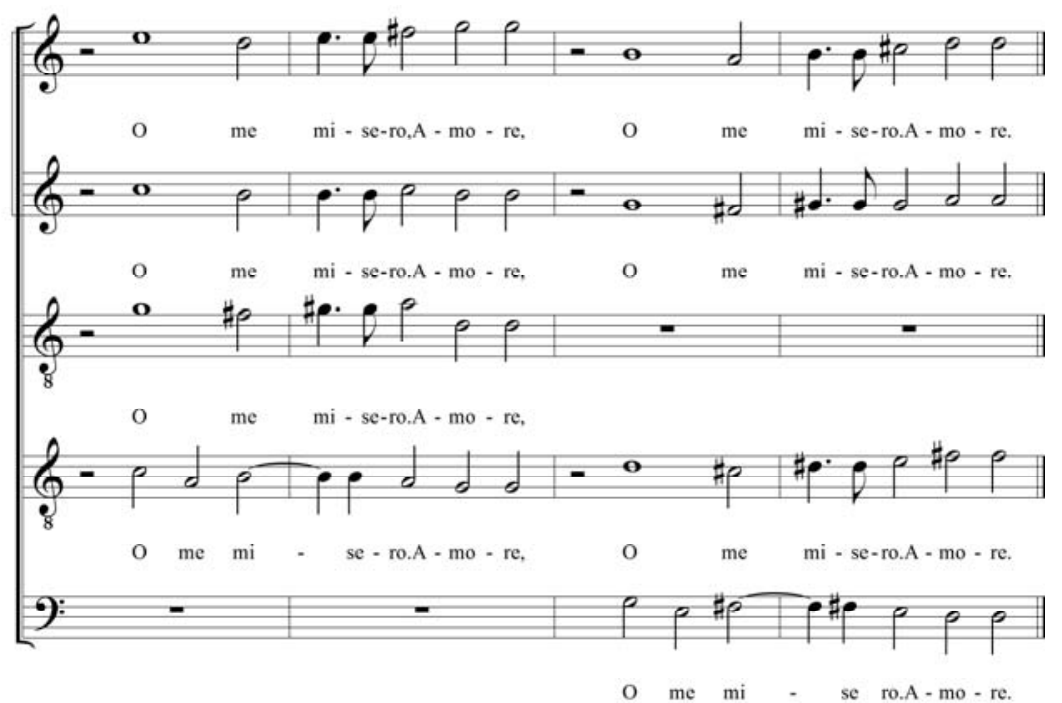

Figura 4: Candida man qual neve- Livro II - c.27-30

Nota-se que, aqui, a palavra amor é utilizada com sua variação amore, e o sentido do texto a coloca de forma pessimista. A descrição do sentimento do narrador como sendo miserável pressupõe uma condição trágica deste sentimento. Para retratar este ambiente, o compositor utiliza as alterações e explora regiões agudas, principalmente da voz do soprano. No entanto, o equilíbrio e a simetria do contraponto são mantidos e as alterações melódicas não caracterizariam uma escrita cromática, nem mesmo dissonante.

Os elementos observados nos quatro exemplos citados são muito comuns nos primeiros dois livros do compositor. Percebe-se que é maior a intenção do compositor de explicar e demonstrar os conceitos daquele texto que escolheu do que de se aprofundar nas relações psicológicas da narração. Já na segunda fase de sua obra, existem algumas diferenças importantes, sobretudo no que diz respeito às relações harmônicas da escrita e à expressividade da narração.

No quinto madrigal do terceiro livro, há uma escrita também baseada na polifonia, embora a técnica contrapontística empregada fosse menos equilibrada. A frase na qual o termo está inserido, Cibo Amor le ministra onde non pera, é tratada de forma seccionada. Percebe-se 
que o compositor a divide em duas semifrases: a primeira Cibo Amor le ministra, e a segunda onde non pera. A diferença que se fazia na primeira fase é a não divisão destas duas frases em seções distintas. Enquanto a voz do soprano inicia a segunda semifrase, as demais ainda estão envolvidas na primeira, o que gera uma sobreposição textual, algo não encontrado anteriormente. Além disso, o tratamento do contraponto é menos simétrico que antes. As entradas não apresentam uma ordem rítmica clara e o motivo principal do trecho não traz uma homogeneidade capaz de identificá-lo com facilidade.

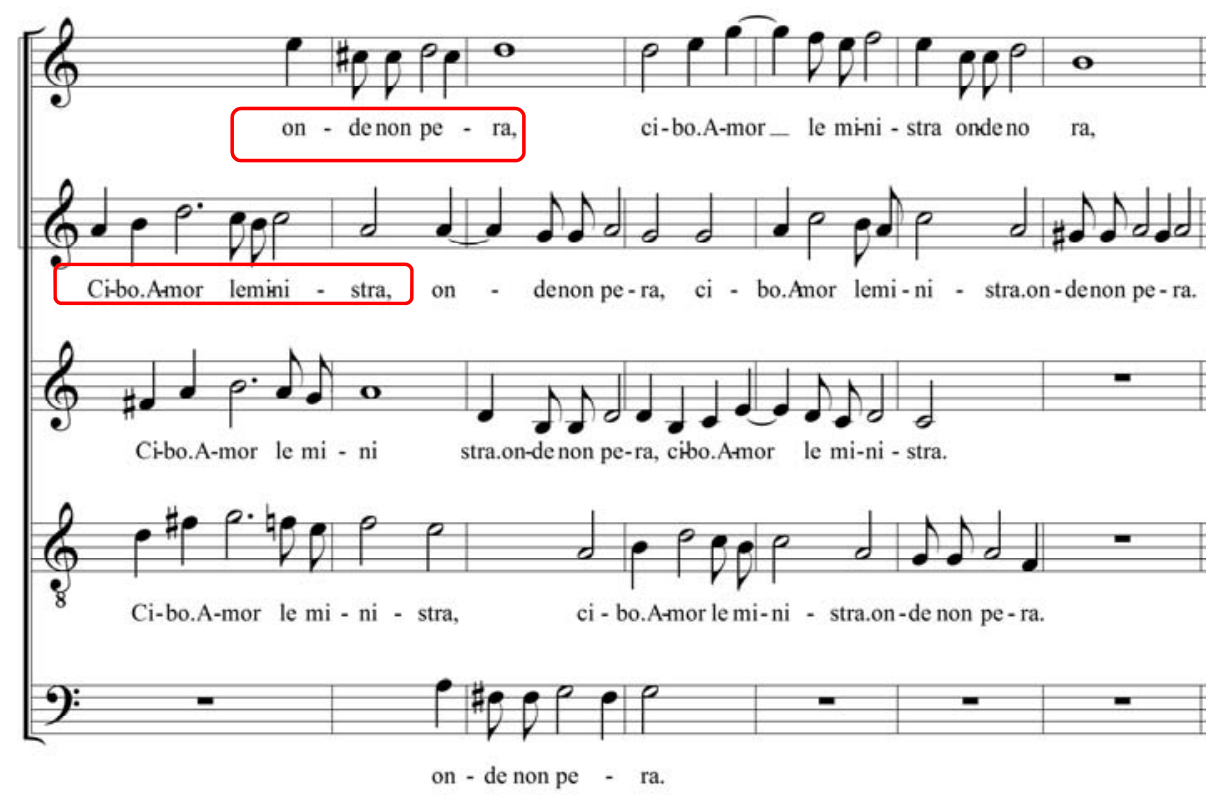

Figura 5: Del bel de’bei vostri occhi - Livro III - c.24-31

Se nos primeiros livros Gesualdo utilizou a técnica contrapontística para unificar a música e o sentido do texto, nesta segunda fase, percebemos a utilização das resultantes harmônicas da escrita como ferramenta. Torna-se aparente o aumento de notas alteradas, que resulta em um efeito sonoro mais instável utilizado como recurso expressivo. Neste primeiro exemplo da segunda fase, nota-se que a palavra em questão está mais destacada da textura musical do que em todos os exemplos anteriores. Mesmo se compararmos o uso da palavra na figura 3 deste texto, quando temos um processo imitativo da escrita, encontramos diferenças importantes. Naquele exemplo, a palavra faz parte de um motivo rítmico que abrange toda a frase, sendo este motivo que se sobressai no trecho. Já no exemplo acima, existe um processo contrapontístico mais complexo, em que mais de um motivo melódico é identificado. A palavra amor tem um motivo específico a ela dentro da trama polifônica, resultando em um 
relevo individual que evidencia um enlace textual mais aprofundado do que antes. O que se tem de concreto é a palavra amor cantada com as notas mais agudas da linha e em movimentos ascendentes, o que garante, assim, que esta palavra se destaque das demais. Exemplo relevante dessa fase está no quinto madrigal do quarto livro, Che fai meco, mio cor (O que fará comigo, meu coração). Em uma das passagens textuais, a narração traz a ideia de que o narrador irá, a partir daquele momento, seguir os caminhos que o seu amor mandar, deh, vanne omai là dove Sue grazie Amor ( Ah, andar para onde mandar Sua graça o Amor) Assim, este texto nos dá a ideia de um caminhar sem destino predefinido, ou mesmo, sem o controle da direção. A música proposta pelo compositor para este trecho vai ao encontro do sentido do texto, e utiliza uma sequência de tríades sem relações harmônicas fortes entre elas. Desse modo, o caminho tomado não corresponde a nenhuma expectativa previamente feita.

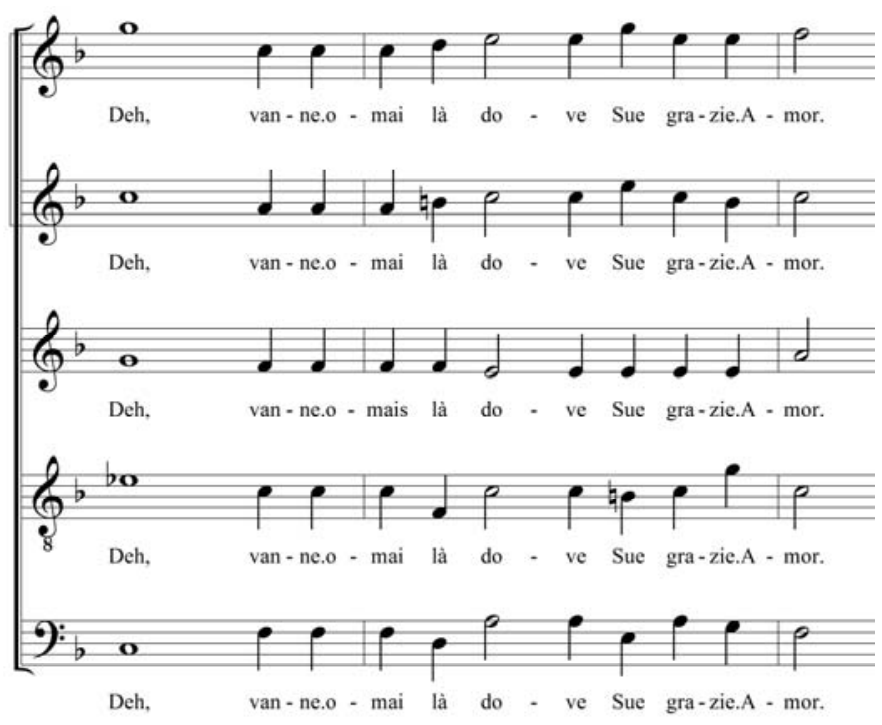

Figura 6: Che fai meco, mio cor - Livro IV - c.5-7

Na sequência de tríades do início deste trecho, identificamos a utilização das relações harmônicas, ou a falta delas, como uma sofisticação da linguagem musical, além de atestar que a música desta fase se apresenta mais experimental do que fora nos dois primeiros livros. Basta compararmos este último exemplo com o da figura 4 para percebermos a diferença. Naquela ocasião, Gesualdo já utilizava algumas alterações melódicas para retratar o sentimento infeliz de um “amor miserável”, como trazia o texto, porém não sem garantir a cadência esperada ao final, o que hoje chamaríamos de uma tríade de "dominante sem 
fundamental" que antecede a "tônica", dando a sensação de resolução à frase. Já neste último exemplo, a situação é oposta, pois mesmo se nos ativéssemos a um pensamento modal, não encontraríamos relações explicáveis, dado que a frase não apresenta um centro definido. $\mathrm{O}$ compositor utiliza justamente a falta destas relações esperadas como elemento retórico, e afasta-se dos procedimentos mais comuns à prática musical, de forma a explorar novas possibilidades expressivas.

Ainda atendo-se a característica experimental da segunda fase, tem-se o exemplo retirado do décimo nono madrigal do quarto livro, em que se observa mais uma vez a sobreposição textual.

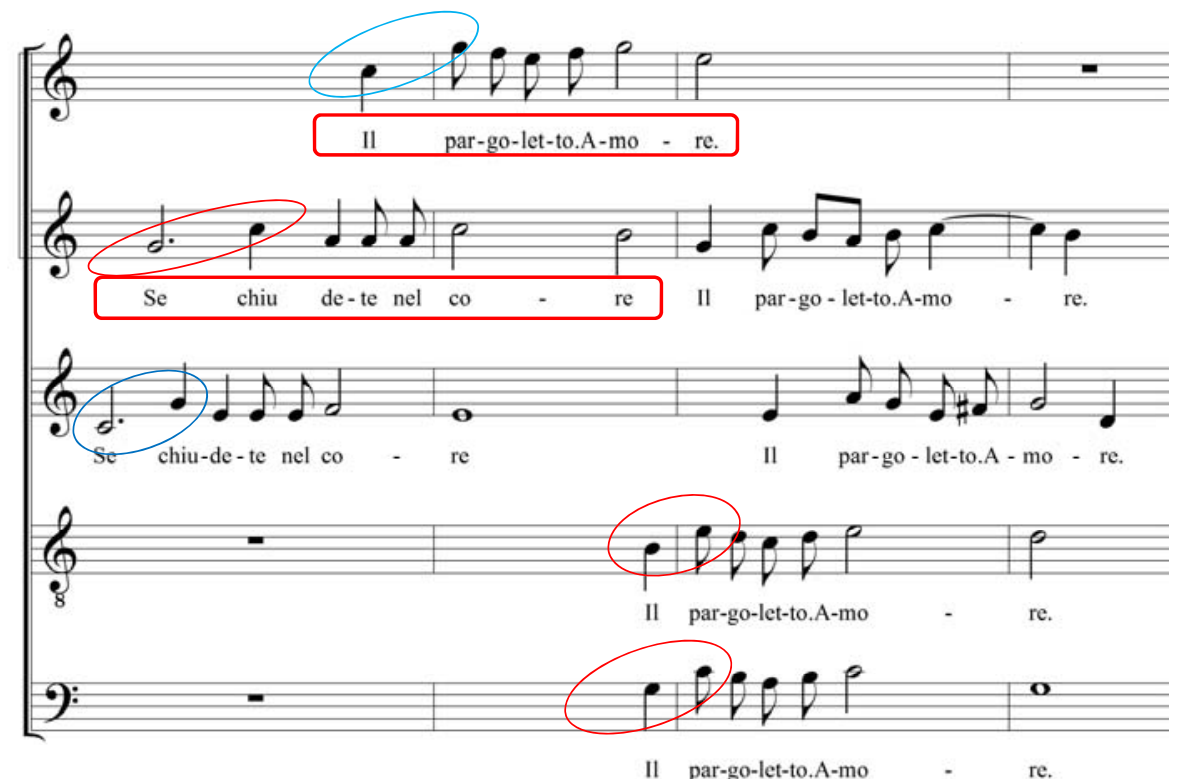

Figura 7: Se chiudete nel core - Livro IV - c.1 - 3

O que torna este exemplo ainda mais distinto do que o de número 5 é o fato de os dois grupos imitativos, que trazem frases diferentes, terem o motivo rítmico-melódico bastante próximo. O intervalo ascendente que caracteriza o início de todas as frases é o mesmo, e a finalização de cada motivo traz semelhanças notáveis. O resultado sonoro deste trecho é peculiar, pois possibilita uma percepção dúbia a partir da qual parece se tratar de uma imitação ao mesmo tempo em que parece existir uma relação de continuidade entre as frases. Para tornar esta característica ainda mais distinta, usa-se o termo amore em contraste com o termo core (coração). As semelhanças sonoras e, no caso desta narração, as semelhanças semânticas 
entre estas duas palavras sugerem uma "brincadeira" ou um "jogo" proposto pelo compositor, sendo mais um indício de seu experimentalismo.

Assim como já observado na figura 5, o exemplo acima traz a percepção de um relevo maior no qual se insere a palavra amor. Se anteriormente identificávamos o contraste de sessões homofônicas com sessões mais contrapontísticas (Figura 3) como forma de ressaltar a narração do texto, aqui percebemos este contraste sendo utilizado dentro do motivo da frase. O uso de figuras rápidas no início da frase seguido de figuras lentas na palavra amore resulta em uma expressividade natural conferida ao termo, pois as figuras mais lentas privilegiam a acentuação natural da palavra amore.Portanto, percebe-se uma preocupação expressiva, ou dramática, mais acentuada nesta segunda fase do que na primeira. Esta expressividade é alcançada principalmente pela escrita motívica que ressalta algumas palavras específicas da narração.

As observações relacionadas ao uso do termo e suas relações com os motivos rítmico e melódico feitos nos exemplos 5 e 7 levam-nos a concluir que, nesta segunda fase, ocorre um entendimento mais individual de algumas palavras dentro da trama polifônica. Por meio desse novo recurso, foi possível aprofundar mais a relação da música com o texto, de modo a relacionar ou afastar motivos de acordo com o significado, por vezes subjetivo, da narração poética. Porém, o experimentalismo desta fase seria ainda mais desenvolvido na fase seguinte, como veremos em seguida.

Quando nos atemos à última fase de suas composições, encontramos os exemplos mais amplos. Os dois últimos livros têm seus madrigais concebidos sobre textos do próprio compositor, como já foi descrito neste trabalho. Contudo, a importância deste fato não deve ser esquecida nesta análise, pois isto conferiu ao compositor a liberdade de que precisava para apresentar seu estilo mais pessoal. Nestas obras tardias, encontram-se quase sempre os mesmos procedimentos utilizados anteriormente, mas de forma aprofundada, muitas vezes revelando um uso exacerbado.

O décimo primeiro madrigal do sexto livro tem seu texto iniciado com a frase Alme d'Amor rubelle (Almas rebeladas do amor). Gesualdo apresenta esta frase de forma contrapontística entre as duas vozes superiores. No entanto, as demais vozes entram na polifonia a partir do 
final do primeiro compasso, já cantando a segunda frase do texto, Che leggiadri suoni (Que graciosos sons). Tem-se aqui mais do que a sobreposição de frases, que já havia sido notada na segunda fase (Figuras 5 e 7). Na realidade, tem-se aqui um discurso textual diferente entre algumas vozes. Esta nova forma de distribuir as frases demonstra uma maior independência que o compositor confere às vozes que integram sua polifonia.

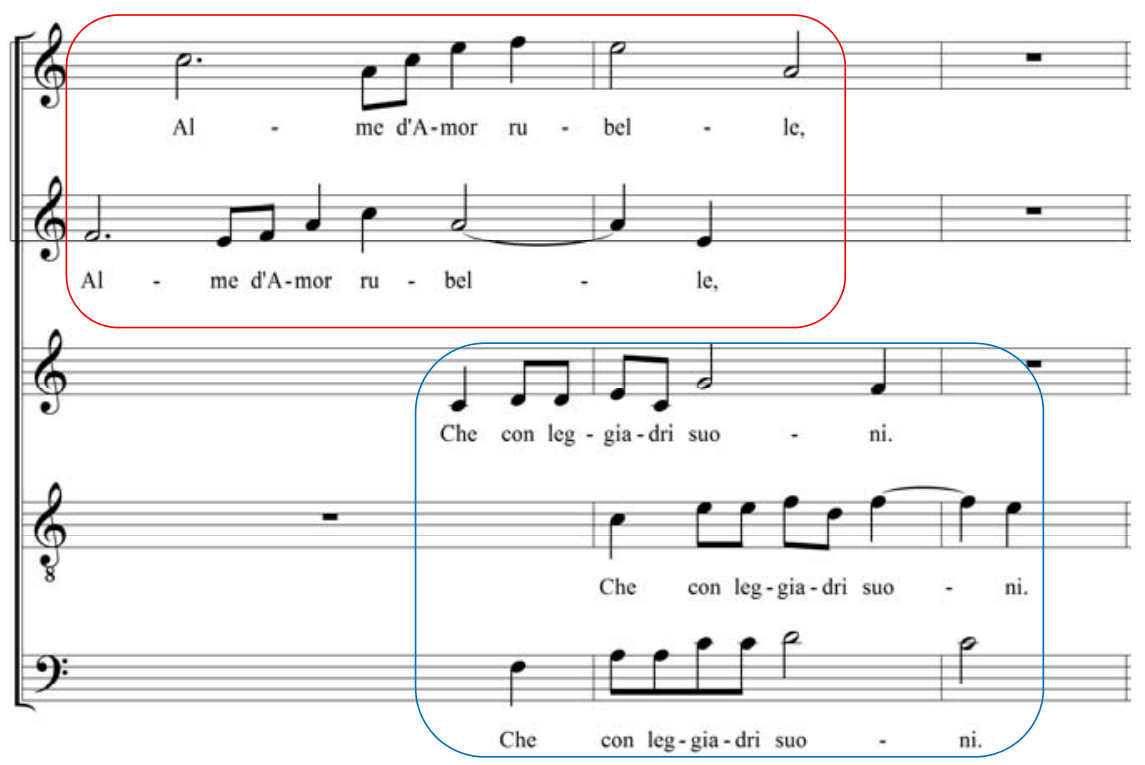

Figura 8: Alme d'Amor rubelle - Livro VI - c. 1 - 2

São vários os parâmetros pelos quais se pode analisar esta mudança na condução textual de seus madrigais. Um deles é a percepção de que Gesualdo passa a tratar as vozes, ou pares de vozes, como personagens distintos dentro de sua narração, o que aumenta suas possibilidades de exploração deste texto e, portanto, estreita a relação deste com a música. Também, podese ir um pouco além nesta análise e aceitar que o compositor passou a considerar cada cantor de sua polifonia como uma personagem dentro de sua trama poética, aproximando-se ou, talvez, influenciando-se pelas novas práticas musicais propostas pela ópera italiana da época. Vale ressaltar que a escrita dos madrigais de Gesualdo, bem como dos madrigais de seus contemporâneos, apresentam características que nos permite supor que foram elaborados para cantores solistas, o que tornaria ainda mais independente cada uma das vozes, e conferiria mais liberdades expressiva e dramática à escrita do compositor.

Ao contrastar este exemplo com os demais relacionados ao termo amor, identifica-se uma mudança importante ocorrida na escrita do compositor ao longo das três fases. Na primeira, 
o uso do termo insere-se completamente à frase. E mesmo quando se utiliza uma escrita imitativa, o motivo principal abrange um segmento da frase maior que a própria palavra, ou seja, não há um relevo independente. Já, na segunda fase, este relevo individual do termo está presente, e através dele foi possível que Gesualdo avançasse na questão expressiva. E por fim, na terceira fase, não existiria apenas um relevo, mas sim uma independência das vozes que canta o termo, o que gerou questões expressivas bem mais complexas.

Quando nos atemos à questão contrapontística da terceira fase, encontramos no décimo sexto madrigal do sexto livro uma situação distinta do uso desta palavra, por se tratar de um uso rítmico. A frase final do madrigal, Amor vince ogni core, está em acordo com todo o texto da obra que desenvolve a ideia da batalha amorosa. Ao longo do madrigal encontramos termos como "sangue", "vitória" e "beijos". Para retratar, ao final, a vitória do amor nesta batalha, o compositor descreve uma situação em que o contraponto é mais rápido e rítmico.

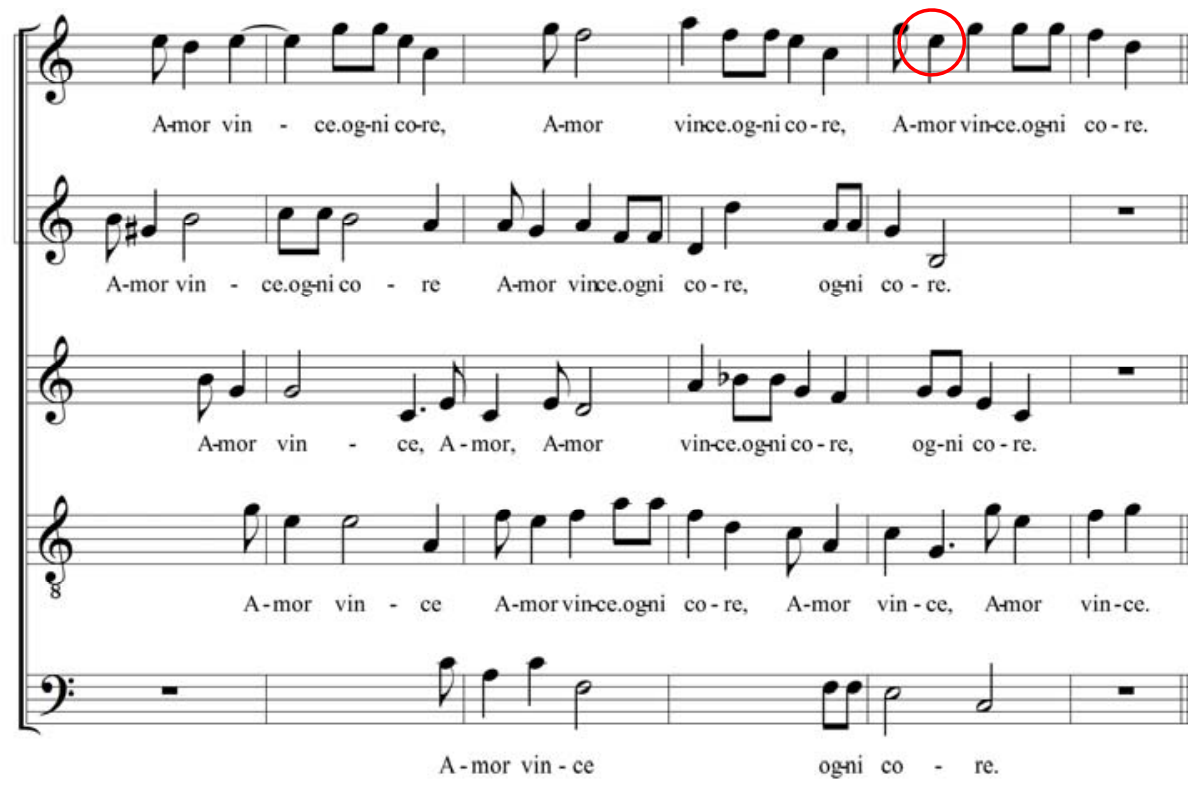

Figura 9: Quel no crudel che la mia speme - Livro VI - c.43 - 48

Evidencia-se, neste exemplo, que o motivo rítmico empregado para a palavra amor é criteriosamente mantido em toda a seção. Entretanto, o mesmo não acontece com o padrão melódico utilizado, pois observamos o intervalo descendente inicial com muitas variações. Temos desde um intervalo de terça maior até o intervalo de segunda menor usada no mesmo motivo. Esta falta de padrão melódico, muito comum na terceira fase, resulta em dificuldades técnicas na execução, principalmente por conta das falsas relações que gera. Certamente, a 
intenção do compositor era causar este efeito sonoro instável. Desta forma, temos a "batalha" referida pelo texto, exemplificada na sonoridade do madrigal.

Apesar de estes exemplos apresentados já demonstrarem como se deu o amadurecimento da escrita textual do compositor, há na palavra morte um elemento revelador. Sua utilização foi constante desde os primeiros madrigais e aumentou ao longo dos livros, acompanhando o processo de amadurecimento da relação com o texto. Assim como no caso da palavra amor, observa-se uma dubiedade em seu sentido. O compositor trabalha o conceito de morte como sendo algo punitivo e trágico ou o assume como uma solução para o sofrimento; nestes casos, a morte passa a ser um desejo.

Temos como exemplo o madrigal do primeiro livro, Baci soavi e cari (Beijos suaves e ternos). A palavra morte está sendo utilizada nesta obra como atestado de bem-estar, pois o narrador atesta que, por causa do amor, não sente as dores da morte. Diante desta situação, a música passa a ser elaborada de forma equilibrada a partir dos conceitos tradicionais da polifonia, como é a característica da primeira fase do compositor.

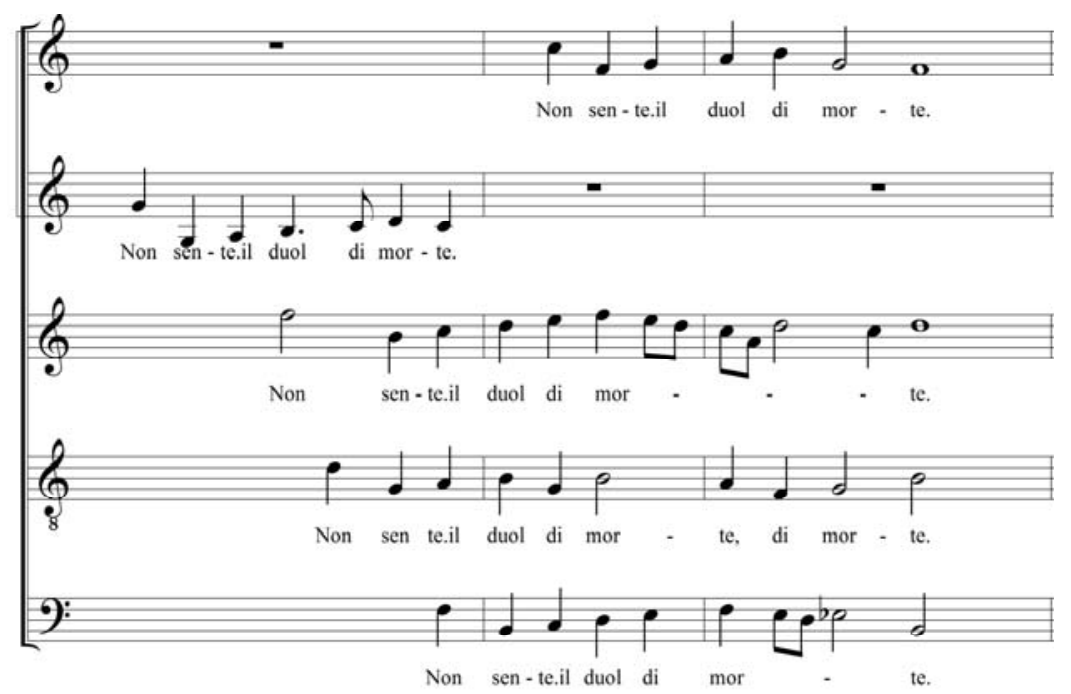

Figura 10: Baci soavi e cari- Livro I - c.19-26

Ainda na primeira fase, tem-se um exemplo oposto ao uso do termo morte. A narração deste trecho descreve que a morte será inevitável, seja por alegria ou por dor, e que, portanto, Non ritardi la morte (Não demora a morte). Percebe-se uma maior ocorrência de notas alteradas, mas assim como no exemplo 1 deste texto, não temos na dissonância e na escrita cromática 
a característica principal desta passagem. O que mais chama atenção é a utilização de uma textura homofônica em que a palavra morte é construída através de notas graves, sendo este o principal recurso expressivo empregado.

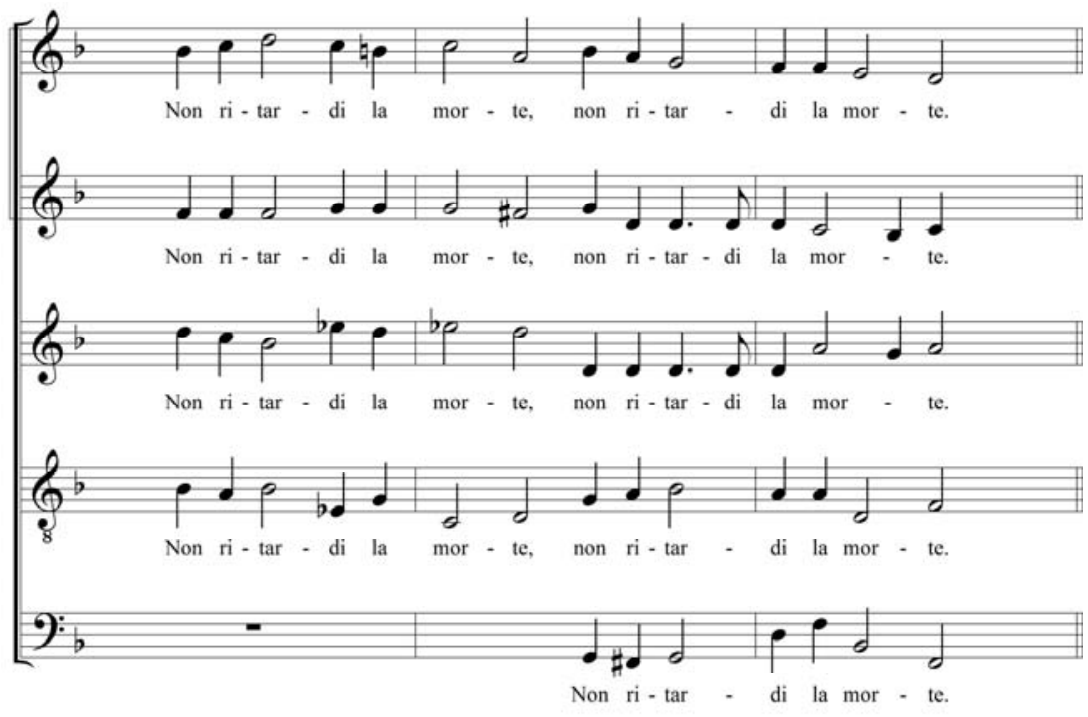

Figura 11: Ma se avverrà ch'io moia - Livro II - c.11 - 13

Exemplo semelhante mostra-nos o madrigal Come esser può ch'io viva (Como posso continuar vivo), que traz em sua narração a ideia sempre contrastante de morte e vida. E mesmo diante de uma atmosfera pessimista trazida pelo texto, a escrita musical continua a seguir os parâmetros da primeira fase.

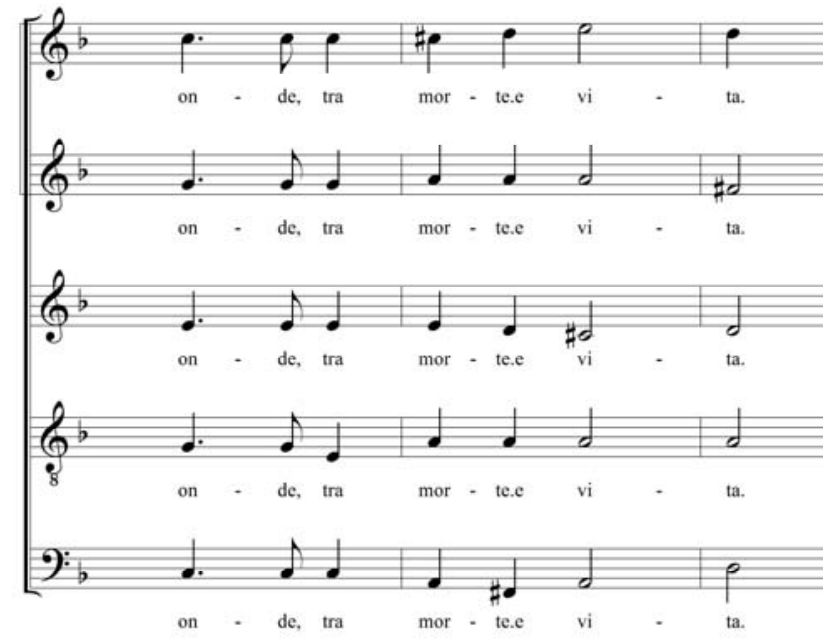

Figura 12: Come esser può ch’io viva - Livro I - c.33 - 34 
Ressalta-se, que a nota mais grave de todo o trecho está na sílaba átona do termo morte. A utilização da região vocal como elemento retórico (Figuras 11 e 12) estará presente ao longo de todas as fases no uso desta palavra, o que demonstra desde já uma mudança considerável com o termo amor, cuja expressividade não requeria do compositor o uso de ferramenta semelhante.

Porém, ao avançarmos para os madrigais da segunda fase, encontramos exemplos mais distintos do uso deste termo. O quarto madrigal do terceiro livro traz o assunto desde seu título, Languisco e moro (Definho e morro). Em sua parte central, o texto desenvolve a frase Sì dolorosa morte (Sim dolorosa morte). Neste ponto, o compositor contrasta a escrita homofônica que vinha desenvolvendo com um trecho imitativo, e, mais uma vez, recorre às regiões mais graves das vozes. A voz do soprano, que seria a mais aguda, está em pausa, e garante o contraste sonoro com a sessão anterior e também a posterior. Além deste contraste, observa-se o motivo melódico que foi destinado à frase em questão. O caminho ascendente composto por intervalos de segundas maiores e menores, cuja nota mais aguda é sempre reservada para a sílaba tônica da palavra morte, gera um efeito sonoro que representa o sentido da palavra dolorosa.

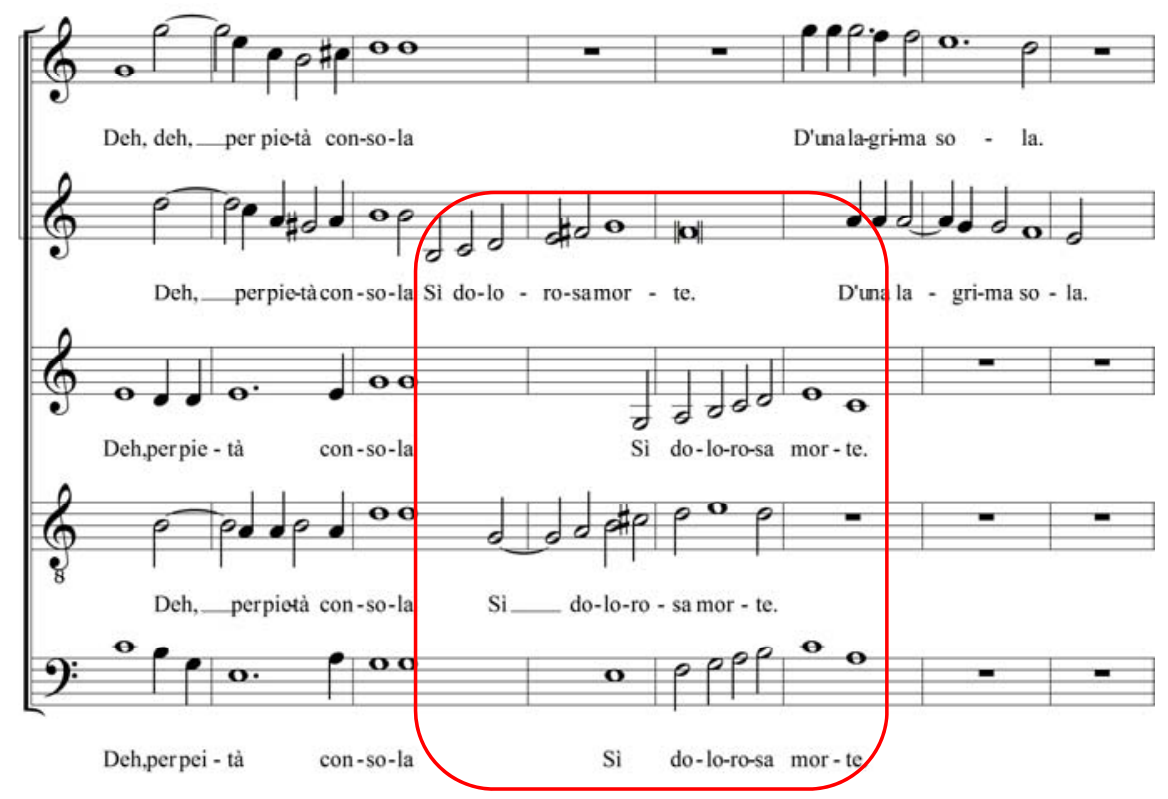

Figura 13: Languisco e moro - Livro III - c.13 - 20 
Apesar de o contraste de textura já ter sido amplamente utilizado na primeira fase, aqui seu uso fica ainda mais acentuado devido à condução melódica dispensada à frase em que consta o termo. Da forma como foi escrita, a palavra morte torna-se o apoio principal de toda a seção, o que garante mais um efeito expressivo conferido à execução musical através da escrita empregada por Gesualdo.

No entanto, ao fim do mesmo madrigal, aparece a frase dolce è morire (doce é morrer), conclusão alcançada após a reflexão amorosa do poema. Para esse caso, a manipulação musical da palavra condiz com o novo sentido, e o predomínio é de um contraponto menos estreito e mais lento.

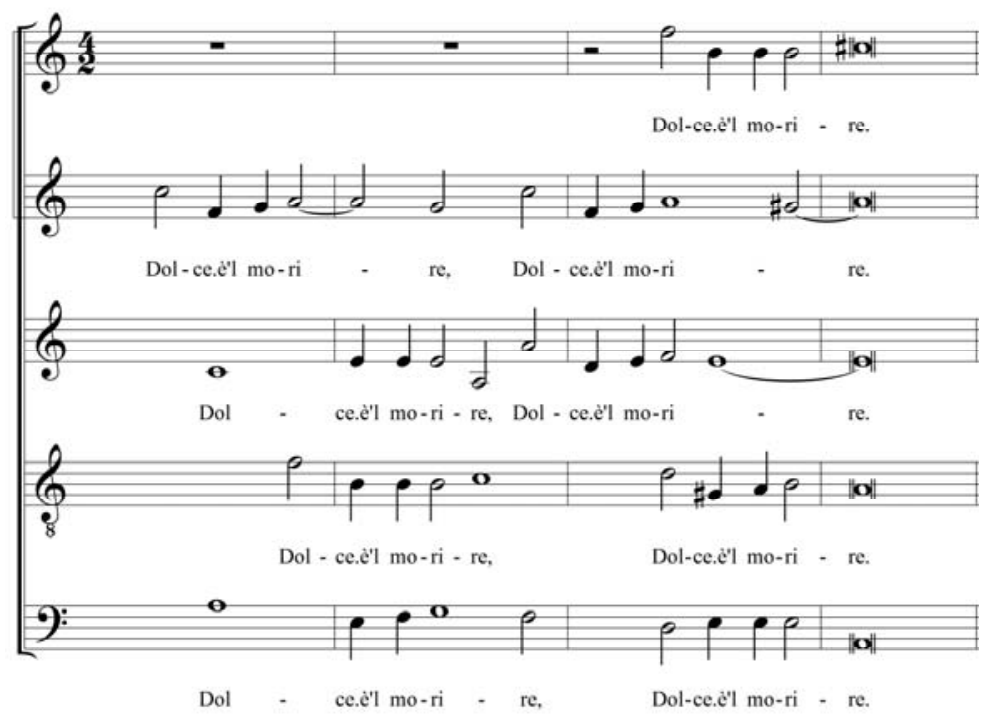

Figura 14: Languisco e moro - Livro III - c.5 - 28

O quarto madrigal do quarto livro, In van dunque, o crudele (É, pois, em vão, o cruel), trata de descrever um sentimento de crueldade. Em seus últimos compassos, a frase Dà la voce al silenzio ed a la morte, que pode ser traduzida como "Dá voz ao silêncio e à morte", é construída com o intuito de encerrar a obra com um efeito sonoro mais pesado e sombrio, explorando as regiões graves das cinco vozes. Destaca-se a nota mais aguda a ser cantada pela voz superior na palavra voce, e, a partir disto, as regiões vocais passam a ficar mais graves, sobretudo na última vez em que a frase ed a la morte é cantada. 


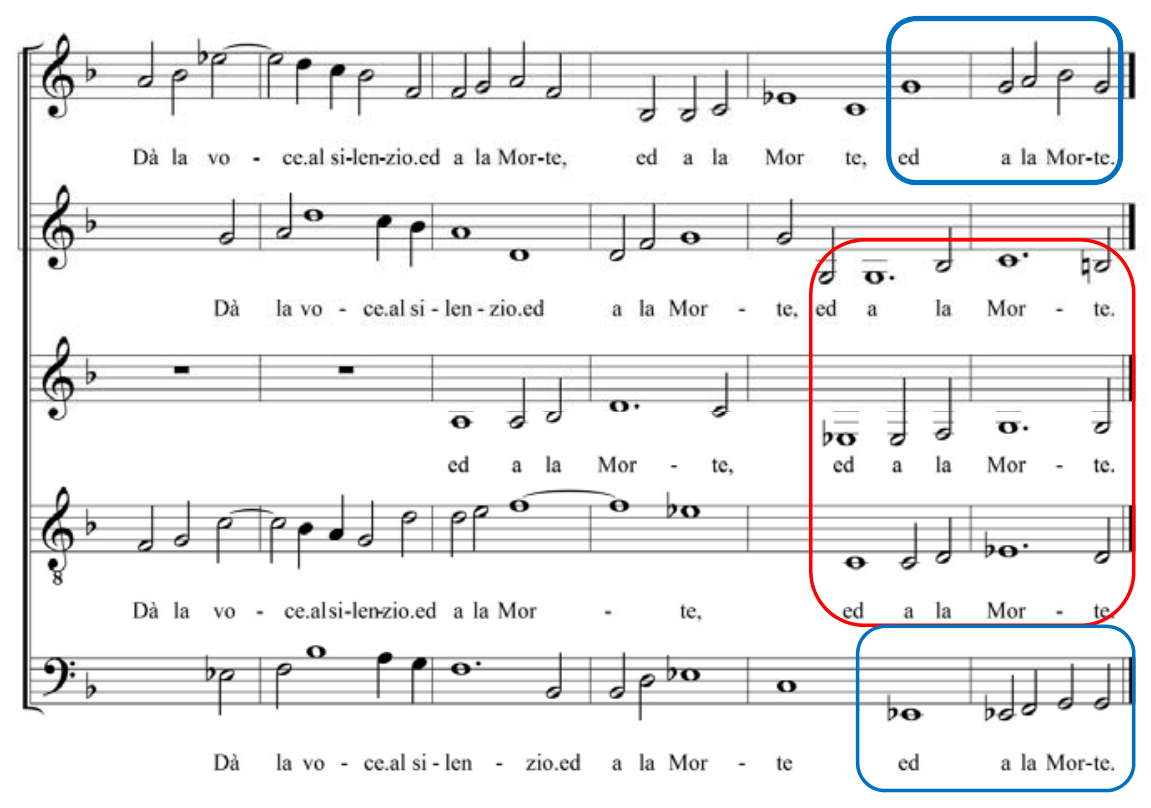

Figura 15: Ivan dunque o crudele - Livro IV - c.24 - 29

Este exemplo nos mostra como o compositor passou a utilizar mais os efeitos sonoros para exemplificar o texto. Além das ferramentas utilizadas anteriormente para ilustrar o texto, como o contraste entre polifonia/homofonia, grave/agudo, e lento/rápido, observamos efeitos sonoros mais elaborados, como, por exemplo, o fato de haver no último compasso uma escrita que manipula as resultantes harmônicas em prol do ambiente sonoro proposto pelo texto. As três vozes intermediárias apresentam notas longas, ao passo que as vozes extremas (sopranos e baixos) realizam movimentos paralelos com intervalos de terça. $\mathrm{O}$ fato de as cinco vozes realizarem notas mais longas com o predomínio de intervalos consonantes, em especial terças e sextas, contrasta com a polifonia mais rápida que prevalecia anteriormente no madrigal, o que resulta em um trecho cujo resultado sonoro se torna "vazio". Desta forma, Gesualdo exemplifica o conceito trazido pelo texto de ir da "voz" ao "silêncio" da morte.

Podemos realizar uma compreensão mais ampla do exemplo acima, se o colocarmos em perspectiva com a utilização do termo anterior, amor, nesta mesma fase de composição. A figura 6 trouxe um exemplo de madrigal do mesmo quarto livro em que identificamos a utilização de uma sequência final de tríades resultantes sem relações harmônicas fortes. Diante do significado daquele trecho do texto poético, a falta de relações harmônicas estava em conformidade com o contexto. 
Comparando-o com o último exemplo, constata-se o mesmo procedimento, isto é, o uso das resultantes harmônicas como recurso de representar na música o significado do texto. Nesse sentido, o que os diferenciam é a importância dos termos para a narração e, mais ainda, para a obra de Gesualdo. Quando o compositor se ocupou da palavra amor, figura 6, ele manipulou as resultantes e colocou-as em sintonia com o texto, porém sem a necessidade de um resultado sonoro mais drástico, por conta do significado do termo. Já no caso da figura 15, o compositor utilizou, além do recurso das resultantes harmônicas, a região vocal das vozes, demonstrando sua ocupação maior em criar um ambiente sonoro mais sombrio e dramático, visto que agora tratava de um termo que também apresentava uma carga dramática maior.

Se na fase intermediária encontram-se indícios da escrita baseada nos efeitos sonoros, na última fase, temos a percepção de ser toda a música baseada nesses efeitos. São desta fase os textos mais dramáticos e trágicos de toda a coleção de madrigais, o que gerou um material farto de exemplos.

Ao final do sétimo madrigal do sexto livro, temos um trecho que descreve a morte como sendo piedosa, ou talvez, esperada, por ser a possível expiação do sofrimento do narrador. Neste contexto, as cinco vozes realizam de forma desencontrada uma polifonia sobre um motivo melódico baseado em intervalos dissonantes que privilegiam as regiões graves das vozes, este procedimento confere à sonoridade um aspecto escuro e instável. Para conseguir este efeito sonoro, identificamos a ocorrência de muitas dissonâncias entre as vozes mesmo na linha melódica de cada voz, não faltando os intervalos cromáticos que se tornam constantes nesta fase. 


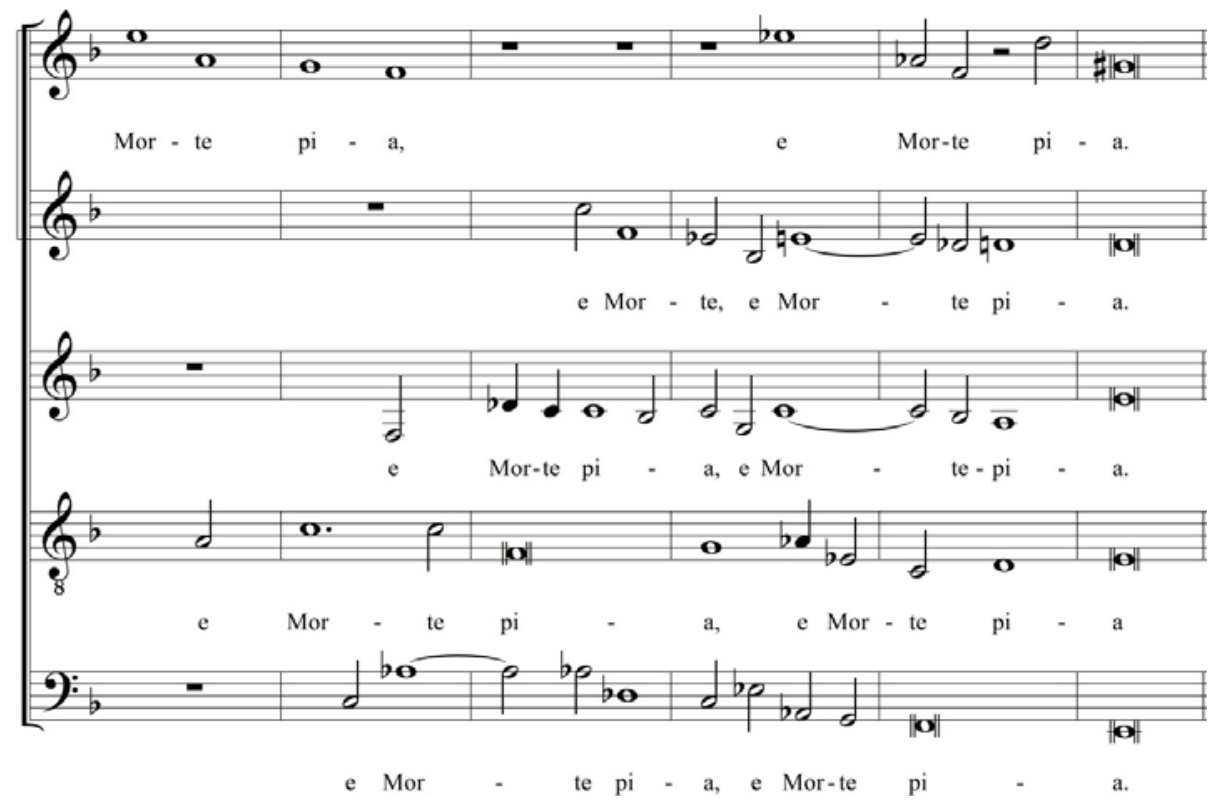

Figura 16: Mille volte il dì moro - Livro VI - c.42 - 48

O que temos de mais inusitado neste exemplo é a forma como o compositor anula os possíveis apoios melódicos das frases, de modo a torná-las extremamente instáveis e dissonantes. Por exemplo, a segunda voz superior, em que o motivo melódico se inicia com a nota Dó e logo na primeira repetição do termo se reinicia com a nota Si uma oitava abaixo. Além disto, a frase segue com uma sequência de notas com intervalos cromáticos que impedem quaisquer intenções de centro melódico. As últimas três notas desta voz, Mi natural, Ré bemol e Ré natural, dão a sensação de que o compositor realizou um ornamento em torno da nota final, o Ré natural, sem que este fosse o centro da frase. Somando a isto as inúmeras dissonâncias causadas pelos intervalos que se formam de forma vertical, ou seja, entre as vozes, tem-se um trecho cuja sonoridade é bastante dissonante. Mesmo quando comparado ao exemplo mais expressivo que temos neste texto, o de número 15, este último, número 16, demonstra o aprofundamento da expressividade da fase final de sua composição. A principal diferença entre as escritas destes dois exemplos (exemplo 15 e exemplo 16) está no total abandono de um centro de repouso harmônico.

No madrigal Moro, Lasso al mio duolo (Morro, definhando do meu sofrimento), que também integra o sexto livro, pode-se identificar a complexidade com que a relação textual se desenvolveu na obra de Gesualdo. No exemplo abaixo, o texto escrito pelo compositor trata dos conceitos de sorte e morte conjuntamente. Percebe-se que, da forma como o texto 
discorre, a sorte a que se refere traz um conceito negativo, pois é tratada como uma sorte dolorosa. Já, a morte acaba assumindo características menos dolorosas, pois o narrador anseia por ela. Desta forma, o cromatismo melódico que pontua as duas palavras na voz superior é descendente para a palavra sorte e ascendente para a palavra morte. Também chama atenção o fato de a palavra sorte ser cantada em homofonia por quatro vozes, enquanto, para a palavra morte, não é permitida nenhuma coincidência rítmica, fato que confere a ela características mais instáveis.

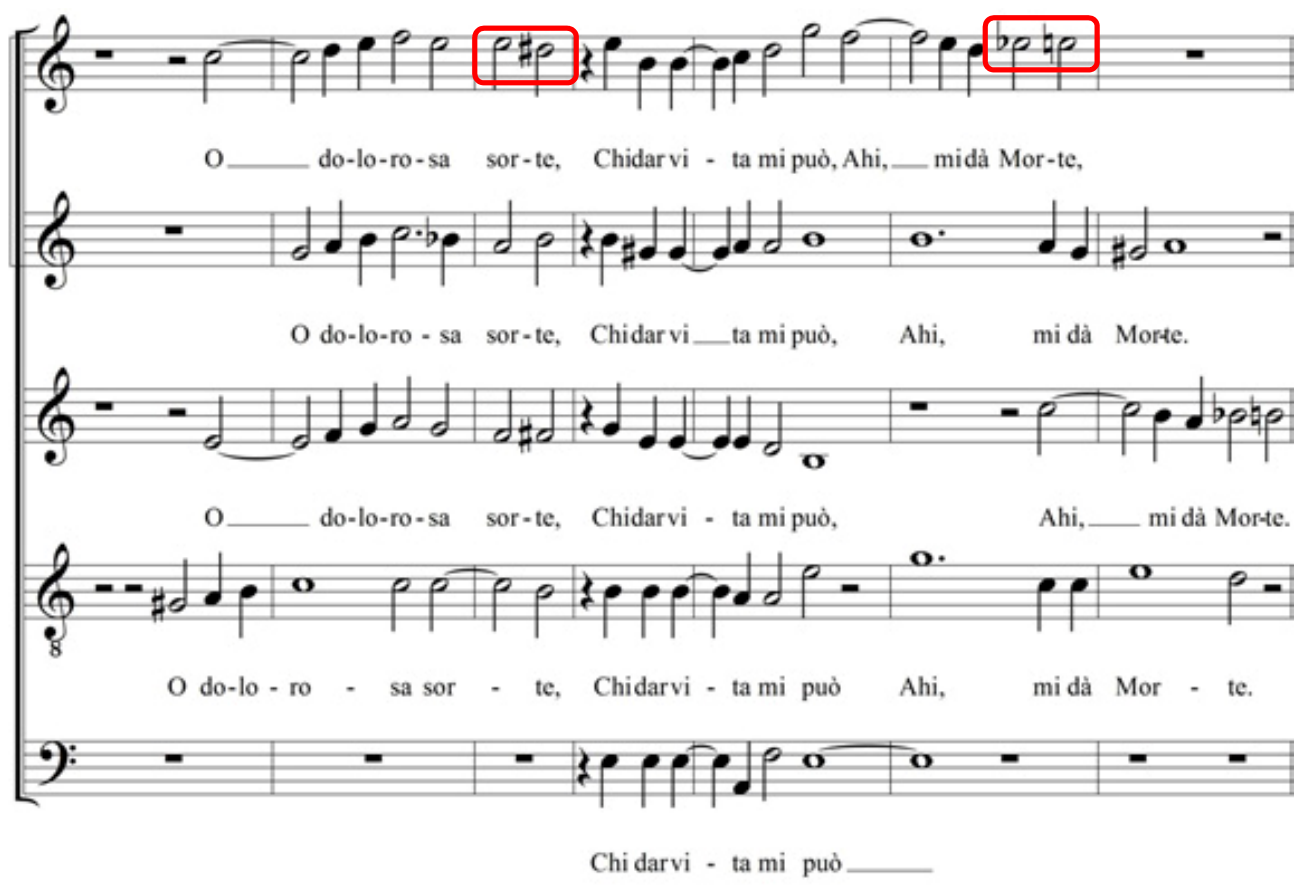

Figura 17: Moro, lasso, al mio duolo - Livro VI - c.31 -36

Assim como já foi observado antes, a palavra que antecede o termo sorte, neste caso dolorosa, também recebe um tratamento especial. A sequência de intervalos ascendentes que mescla graus conjuntos e semitons alcança o ápice na sílaba tônica desta palavra. Após isto, promove intervalos descendentes em que trata do termo sorte, que neste caso, está em contraste com o termo morte. A diferença com a figura 13 é que neste último, de número 17 , o compositor mescla mais de uma ferramenta retórica.

Encontramos nos primeiros compassos deste mesmo madrigal um exemplo representativo da escrita tardia de Gesualdo. A variação do termo morte, sendo aqui Moro (forma antiga da 
primeira conjugação do singular do verbo morire), demonstra a escrita cromática que se tornou típica do compositor. A diferença deste cromatismo que vemos mais comumente nas primeiras fases, figuras 1, 4 e 11, está no uso do cromatismo de forma harmônica e não só melódica. Em outras palavras, mais do que promover intervalos de semitons dentro das linhas melódicas, a escrita musical contempla muitos procedimentos cromáticos entre todas as vozes, gerando assim um efeito sonoro mais impactante. Ressalta-se também o caráter "escuro" do trecho, que privilegia as regiões graves das vozes. Este recurso foi muito explorado em quase todas as fases de sua composição, mas temos aqui um uso mais exagerado. Até mesmo a voz superior foi suprimida do trecho, da mesma forma como já havia sido identificado na figura 13 deste texto.

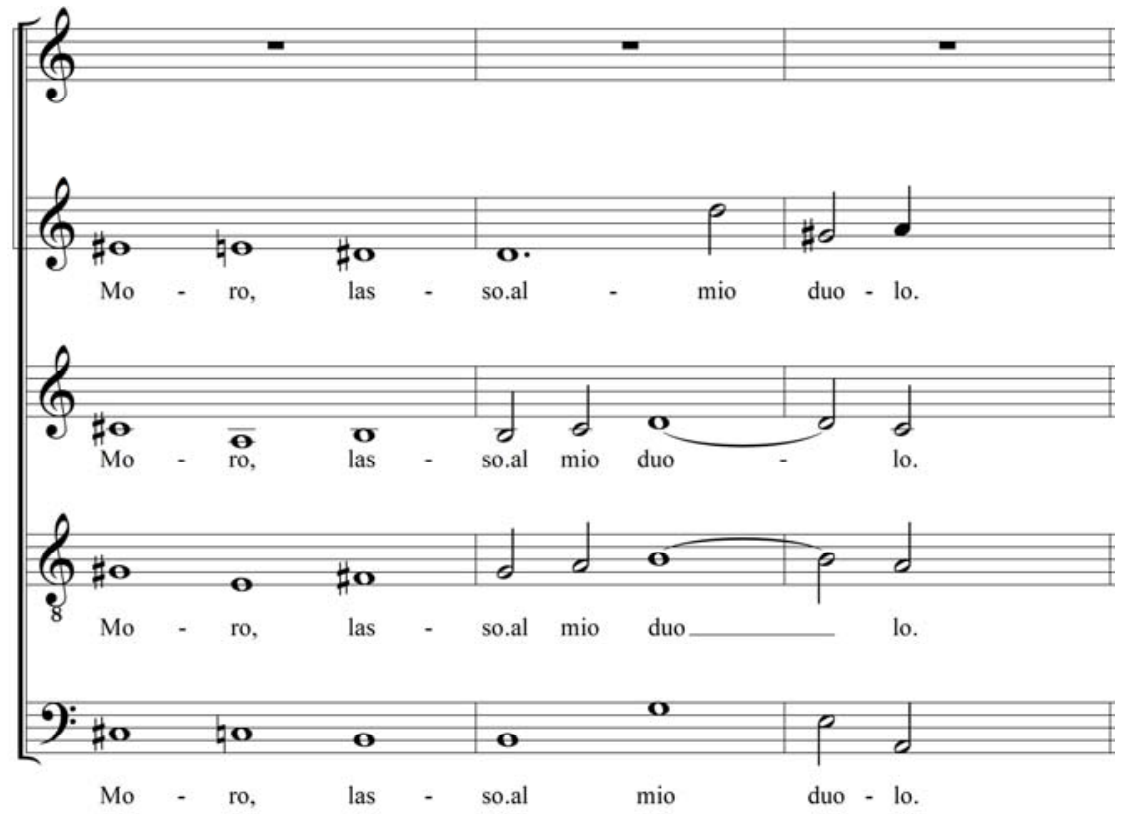

Figura 18: Moro, lasso, al mio duolo - Livro VI - c. 1 - 3

Através desta escrita, o compositor consegue elaborar uma passagem musical que chama atenção pelo caráter exótico da música. Os primeiros três compassos chamam atenção de quem os ouve, e também de quem os cantam, por conta da sonoridade agressiva que gera. A escrita que combina intervalos melódicos cromáticos com resultantes harmônicas, também cromáticas, causa um efeito inusitado. Vale ressaltar que, na sequêencia destes primeiros compassos, o madrigal passa a construir um centro modal sobre a escala do modo Eólio com 
centro na nota $\mathrm{Mi}$; ou seja, o impacto mantém-se, pois as tríades inicias são também contraditórias dentro do discurso seguinte da música. Certamente, estes elementos todos causados por trechos como este foram programados e esperados por Gesualdo, quem se utiliza desta estranheza sonora como recurso dramático.

Um exemplo que vai ao encontro desta ideia agressiva da terceira fase aparece no segundo madrigal do quinto livro, S'io non miro non moro (Se não vejo, não morro). Neste caso, o poema do madrigal é encerrado com a repetição da palavra morte, e a sensação de quem o ouve é que esta palavra está sendo gritada, ou mesmo, clamada pelo narrador.

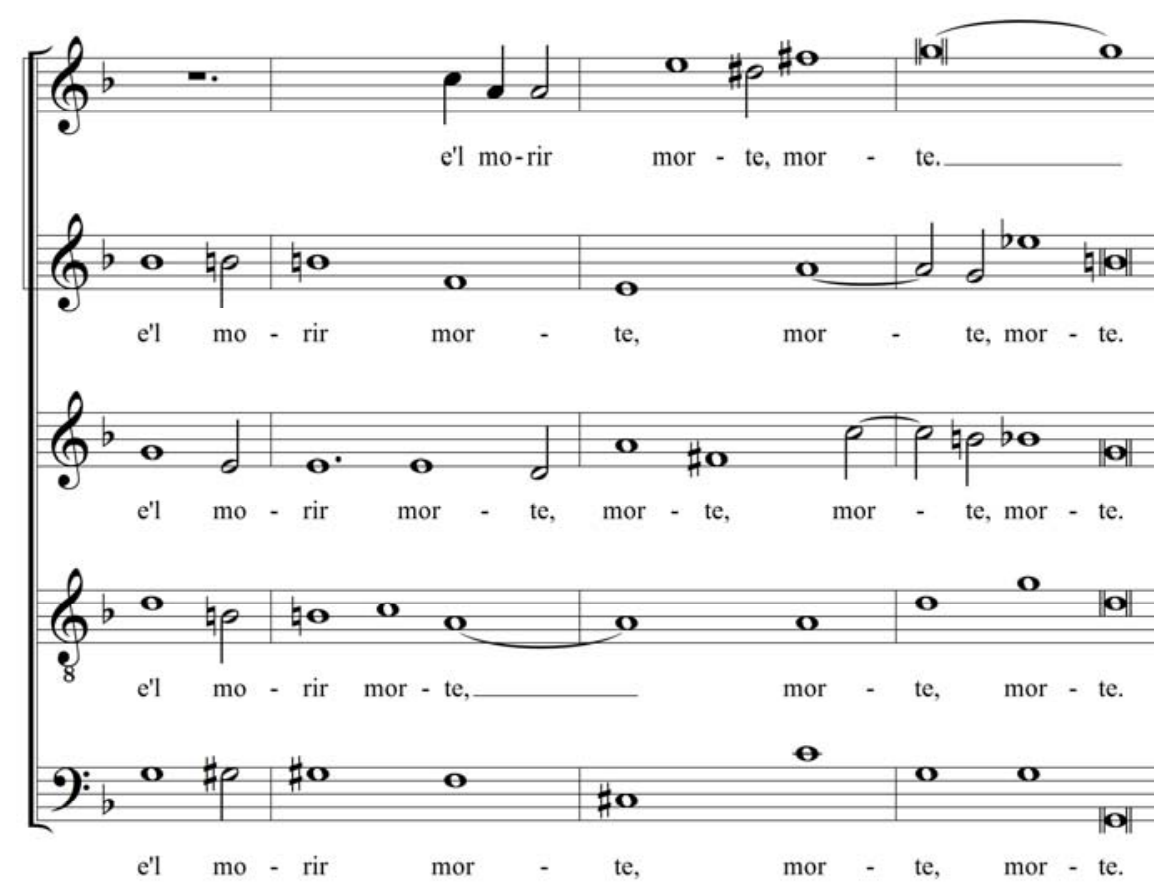

Figua 19: S'io non miro non moro - Livro V - c.27 - 30

O que temos neste trecho que colabora com o "desespero" do texto é a sequência da escrita cromática e das falsas relações melódicas geradas por ela, diluídas entre as vozes. Gera-se, assim, uma finalização sonora instável e dissonante.

Há ainda nesta fase um exemplo revelador sobre até que ponto chegou a escrita cromática de Gesualdo. No quarto madrigal do quinto livro, o compositor dedica os últimos doze compassos à descrição da variação do termo morte com intervalos cromáticos ascendentes e descendentes que elaboram um processo imitativo que descrevem o sentido da morte. A 
frase completa deste trecho ( $O$ d'amarti o morire) reserva um início homofônico para o verbo inicial, amarti, e segue construindo o termo morire com um contraponto assimétrico e extenso.

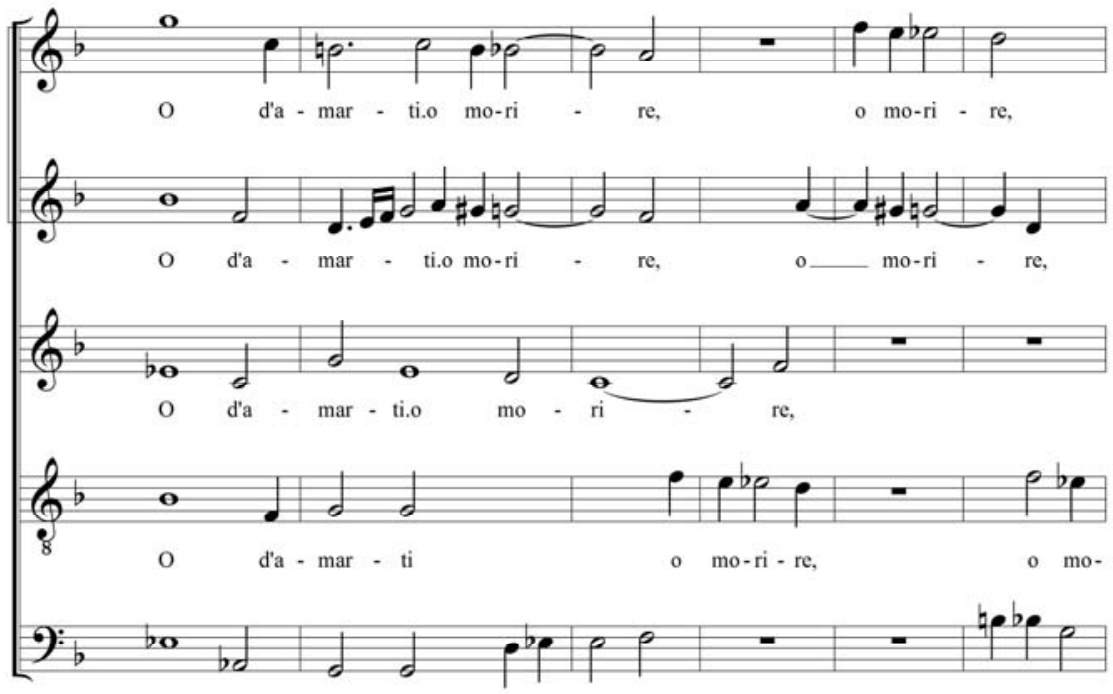

o d'a - mar - ti o mo - ri - re, o mo-ri -

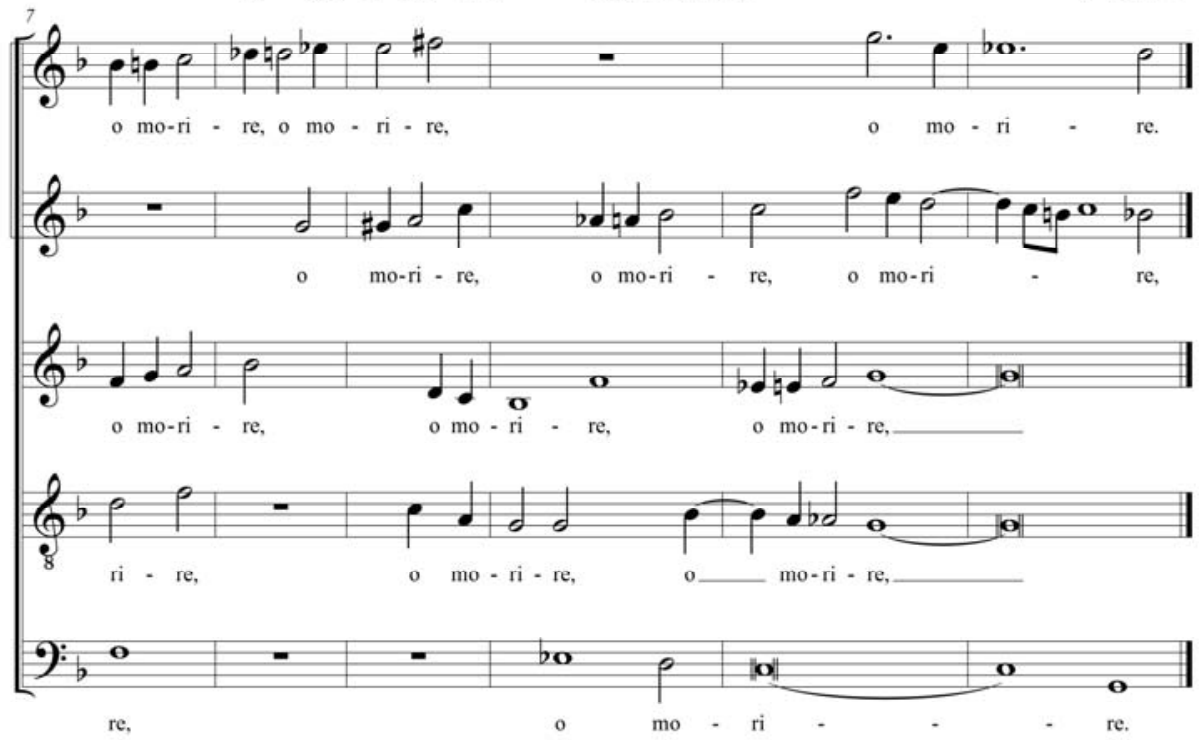

Figura 20: Dolcisima mia vita - Livro V - c.34 - 45

O trecho acima não apresenta apenas a escrita cromática como ambientação textual; certamente está nos intervalos cromáticos a ferramenta principal utilizada pelo compositor. O que mais chama atenção neste exemplo é a extensão do trecho em que se identifica um processo ininterrupto desta ferramenta musical. Em outros termos, na terceira e última fase de sua composição, Gesualdo coloca a expressividade e a dramaticidade que julga necessária 
à frente de qualquer outro requisito musical, até mesmo do equilíbrio formal de seus madrigais.

Por fim, destaca-se a relação compensatória que há entre os dois termos utilizados por este estudo, amor e morte, ao longo dos livros de Gesualdo. O parâmetro utilizado para a escolha dos exemplos foi justamente a utilização destes termos em formas representativas, ou seja, revelando procedimentos que ocorrem mais vezes. Desta forma, ficou muito claro que o primeiro termo, amor, apresentou numericamente muito mais relevância nas duas primeiras fases, enquanto que o segundo, morte, foi preponderante na terceira e última fase do compositor.

\section{3 - Conclusão}

A partir dos exemplos apresentados neste texto, tornou-se possível concluir que a principal diferença da escrita de Carlo Gesualdo ao longo de suas três fases de composição está na expressividade que ele desejava conferir a cada trecho $\mathrm{Na}$ medida em que seus livros de madrigais avançam para as fases seguintes, sua preocupação narrativa e dramática aumenta e, consequentemente, o uso de suas ferramentas expressivas torna-se mais evidente. Também foi possível identificar que as ferramentas são as mesmas e apresentam, porém, aprofundamentos distintos.

Em sua primeira fase, Gesualdo ocupava-se mais em explicar a narração escolhida. Para isto, sua escrita polifônica apresentava uma clareza textual e motívica que facilitava o entendimento. Esta clareza era conquistada através de seções textuais bem delimitadas. $\mathrm{O}$ uso das resultantes harmônicas era bastante contido, resumindo-se a alterações melódicas pontuais que não caracterizavam uma escrita dissonante.

$\mathrm{Na}$ fase intermediária, ou segunda fase, a escrita mais experimental encontrada apresentava contornos narrativos mais desenvolvidos. As seções textuais delimitadas foram substituídas por sobreposições de frases que conferiam mais independência às vozes. Os termos 
escolhidos para serem analisados passaram a apresentar um relevo mais individualizado do que na fase anterior, e puderam ser trabalhados de forma mais expressiva dentro do contorno melódico de cada frase. A manipulação das resultantes harmônicas passou a ser mais comum e firmou-se como uma ferramenta expressiva importante para este segmento da obra.

Quando analisamos o uso destes dois termos na terceira e última fase, encontramos uma preocupação expressiva mais aparente que antes. $\mathrm{O}$ relevo melódico conferido individualmente aos termos textuais da segunda fase passa a ser bem mais explorado agora. A independência das vozes permite ao compositor tratá-las como personagens distintos da narração poética, apresentando relações mais aprofundadas. O uso das resultantes triádicas torna-se ainda mais constante e o cuidado do compositor em não permitir centros de repousos harmônicos cria passagens de efeitos sonoros inusitados.

Por fim, a comparação dos dois termos, amor e morte, foi reveladora. Por conta dos significados de cada um, percebeu-se que o termo amor foi mais frequente e mais importante na primeira e na segunda fase, ao passo que o termo morte se mostrou como o principal termo na fase final. Para descrever e ambientar o primeiro termo, Gesualdo utilizou os recursos musicais mais comuns ao Renascimento, como o contraste de textura, escrita cromática e dissonante e exploração de regiões vocais contrastantes. Quando se ocupava do segundo, ele reunia mais de um recurso ao mesmo tempo, de forma a tornar a execução do termo morte sempre mais carregada de expressividade e de dramaticidade.

\section{Referências}

1. MISURACA, P. (2000). Carlo Gesualdo, Principe di Venosa. Palermo: L'Epos.

2. WATKINS, G. (1991). Gesualdo: The Man and His Music. Oxford: Clarendon Press.

3. IUDICA, G. (1993). Il Principe dei musici. Palermo: Sellerio editore. 


\section{Referências de partituras e gravações}

1. GESUALDO, C (2010). Don Carlo Gesualdo (1566-1613), The Complete Madrigals, 6 volumes. The Kassiopeia Quintet. Netherlands: GLO 5241, Globe Records.

2. WEISMANN, W. WATKINS, G. (1980). Gesualdo di Venosa - Madrigale für Fünf Stimmen - Erste Buch. Leipzig: Deutscher Verlag für Musik.

3. WEISMANN, W. WATKINS, G. (1988). Gesualdo di Venosa - Madrigale für Fünf Stimmen - Zweites Buch. Leipzig: Deutscher Verlag für Musik.

4. WEISMANN, W. WATKINS, G. (1980). Gesualdo di Venosa - Madrigale für Fünf Stimmen - Drittes Buch. Leipzig: Deutscher Verlag für Musik.

5. WEISMANN, W. WATKINS, G. (1980). Gesualdo di Venosa - Madrigale für Fünf Stimmen - Viertes Buch. Leipzig: Deutscher Verlag für Musik.

6. WEISMANN, W. WATKINS, G. (1980). Gesualdo di Venosa - Madrigale für Fünf Stimmen - Fünftes Buch. Leipzig: Deutscher Verlag für Musik.

7. WEISMANN, W. WATKINS, G. (1982). Gesualdo di Venosa - Madrigale für Fünf Stimmen - Sechstes Buch. Leipzig: Deutscher Verlag für Musik.

\section{Literatura recomendada}

1. BURMEISTER, J. (1993). Musical Poetics (Musica Poetica: 1606). Tradução: Benito V. Rivera. New Haven and London: Yale University Press.

2. EINSTEIN, A. (1971). The Italian Madrigal. New Jersey: Princeton University Press, second printing.

3. GARBUIO, R. L. (2015). Os Madrigais de Carlo Gesualdo: Um estudo interpretativo à luz de seu ideal poético. Orientação: Dr. Carlos Fernando Fiorini. Tese de doutorado. Campinas: Universidade Estadual de Campinas.

4. LOWINSKY, E. E. (1961). Tonality and Atonality in Sixteenth-Century Music.

California: University of California Press.

5. MANIATES, M. R. (1979). Mannerism in Italian music and culture, 1530-1630.

North Carolina: The University of North Carolina Press.

Notas sobre os autores 
Rafael Garbuio é doutor pela Universidade Estadual de Campinas, UNICAMP, onde desenvolveu sua pesquisa a cerca da obra de Carlo Gesualdo, sob a orientação do Professor Doutor Carlos Fiorini. Formou-se técnico em violão Clássico pelo Conservatório Municipal de Pirassununga "Cacilda Becker" no ano 2001 e bacharel em Regência Plena e Mestre pela Universidade Estadual de Campinas. É membro permanente do grupo de Pesquisa REGÊNCIA - ARTE E TÉCNICA da UNICAMP e do grupo vocal Camerata Anima Antiqua, especializado no repertório do Renascimento.

Carlos Fiorini é doutor em Música (Regência), Mestre em Artes (Música). Graduou-se em Regência e Composição pela UNICAMP - Universidade Estadual de Campinas. Desde 1998 é professor de Regência Coral e Orquestral do Departamento de Música da UNICAMP. De 2005 a 2008 foi assistente e Regente Principal da Orquestra Sinfônica de Campinas. Fundou em 1996, a Camerata Antiqua Anima, um conjunto vocal dedicado à música renascentista, do qual ainda é seu Regente e Diretor Artístico. Criou em 2009, no Instituto de Artes da UNICAMP, um Grupo de Pesquisa de regência coral e regência orquestral com o nome "Regência - Arte e Técnica", que inclui o Coro do Departamento de Música e a Camerata Antiqua Anima. 